Rafal Pitera

Kancelaria Usług Finansowo-Księgowych „Doradca”, Rzeszów, Polska

\title{
Ocena możliwości wykorzystania metod dyskryminacyjnych w badaniu kondycji finansowej przedsiębiorstw
}

\author{
The assessment of possibilities of using discriminatory \\ methods in examining the financial position of enterprises
}

\begin{abstract}
Streszczenie: Artykuł dotyczy analizy oraz oceny kondycji finansowej przedsiębiorstw. Osiem metod dyskryminacyjnych poddano weryfikacji pod względem ich skuteczności prognostycznej na próbie danych pochodzących z okresu trzech lat działalności 50 przedsiębiorstw, które w ostatnim okresie działalności wykazywały stratę netto. Zgodnie z zasadą obiektywizmu wśród badanej próby znalazły się przedsiębiorstwa z różnych branż, o różnym profilu działania oraz różnej wielkości posiadanych aktywów i wykazywanych obrotów w analizowanym okresie. Wszystko po to, by uniknąć jednoznacznych wyników badań faworyzujących dany model.

Przedstawione wyniki uporządkowano według wiarygodności prognostycznej, a metody dyskryminacyjne poddane badaniu należą do najczęściej wykorzystywanych przez badaczy związanych z dziedziną analizy finansowej.

Otrzymane wyniki skonfrontowano z syntetyczną metodą klasyfikującą badane jednostki na tle rynkowej konkurencji. Wartości płynące z modeli dyskryminacyjnych są bardzo zróżnicowane. Dlatego jako weryfikator zaprezentowano wyniki badań z analizowanego okresu przy wykorzystaniu punktowej metody oceny ryzyka bankowego zaproponowanej przez Artura Hołdę. Pozwala ona na określenie miejsca badanego przedsiębiorstwa w danej branży. Konfrontacja otrzymanych wyników płynących z modeli dyskryminacyjnych oraz metody bankowej stanowi swoiste podsumowanie artykułu oraz ocenę wiarygodności przedstawionych modeli.
\end{abstract}

\begin{abstract}
The article treats about the analysis and assessment of the financial condition of enterprises. Eight discriminatory methods were verified in terms of their predictive efficacy data from a sample of 50 companies from the period of 3 years of activity, which recently showed a net loss for the business. In accordance with the principle of objectivity, of the sample included companies from various industries, profile, action and different sizes of owned assets and reported turnover during the period.

The results presented in order of predictive credibility and discriminatory methods tested are the most commonly used by researchers associated with the field of financial analysis.

The results were confronted with a synthetic method classifying analyzed data against market competition. The value of the discriminatory models are very diverse. Therefore, as a verifier the Points of Banking Risk Assessment Methods proposed by Arthur Hołda were presented. The confrontation of the results obtained with the models and methods of discriminatory banking provides a summary of the article and an assessment of the reliability of the presented models.
\end{abstract}


Słowa kluczowe: analiza finansowa; kondycja finansowa; metody dyskryminacyjne; przedsiębiorstwo; sprawozdanie finansowe; upadłość; zarządzanie finansami

Keywords: financial analysis; financial condition; discriminatory methods; corporation; financial report; business failure; financial management

\section{WSTĘP}

Analiza finansowa należy do jednego z najważniejszych obszarów z zakresu finansów przedsiębiorstwa. Jest to dyscyplina, dzięki której możliwe staje się ocenienie zarówno wiarygodności kontrahentów przez przedsiębiorstwa, jak i kondycji finansowej przez banki zamierzające udzielić kredytu. Jest to także narzędzie, którym posługują się potencjalni inwestorzy, którzy myślą o zainwestowaniu w daną spółkę, oraz szereg innych instytucji i podmiotów mających zamiar alokacji posiadanego kapitału.

Szczególnie istotny jest tutaj rozkwit działu analizy finansowej bazujący na modelach opartych o funkcje dyskryminacyjne. W uproszczeniu są to modele, które poprzez wyselekcjonowanie odpowiednich (w domyśle najbardziej wiarygodnych) wskaźników finansowych łączą je ze sobą poprzez wzór funkcji przypisującej poszczególnym miernikom odpowiednie wagi. Pomysł taki wprowadził do przedmiotu analizy finansowej E.I. Altman, który zaproponował pierwszy model w 1968 roku (Kitowski, 1997: 77). Podobny proces rozwoju dyscypliny jest widoczny także w Polsce, od momentu skonstruowania metody przez Pogodzińską oraz Sojaka.

Najważniejszym faktem, jaki należy podkreślić, prócz samej liczby powstałych modeli, jest ich wiarygodność. Jest to drugi argument, obok dużej ilości wskaźników, wskazywany przez twórców powyższych modeli. Niemal każdy z autorów w swojej prezentacji opisuje badania, jakim poddany został model oraz związaną z tym wiarygodność prognostyczną. W zdecydowanej większości autorzy przedstawiają skuteczność nieschodzącą poniżej 90\%.

W tym miejscu uwidacznia się główny cel przeprowadzonego badania. Otóż należy rozstrzygnąć kwestię: czy na przestrzeni czasu od powstania metody do chwili obecnej wiarygodność ta nie ulega obniżeniu, co bezpośrednio wiąże się z dalszą jej użytecznością oraz praktycznym wykorzystywaniem przy ocenie kondycji finansowej przedsiębiorstw przez analityków finansowych, inwestorów czy też osób badających sprawozdania finansowe.

Na powyższe pytania odpowiada dalsza część artykułu, który na podstawie przeprowadzonej weryfikacji ośmiu metod dyskryminacyjnych przedstawia skuteczność prognostyczną za okres trzech lat objętych badaniem (lata 2009-2011).

Ze względu na dużą popularność, jaką cieszą się metody wykorzystujące funkcję dyskryminacyjną, w dalszej części opisano kilka najpopularniejszych z nich, a następnie poddano weryfikacji na próbie 50 przedsiębiorstw, które co najmniej w ostatnim spośród trzech okresów badawczych wykazywały w działalności stratę netto i zatrudniają w przeliczeniu na pełne etaty powyżej 250 pracowników. Dodatkowo, aby badania przeprowadzić w sposób obiektywny, wśród badanej próby znalazły się przedsiębiorstwa z różnych branż, o różnym profilu działania oraz o różnej wielkości posiadanych aktywów i wykazywanych obrotów 
w analizowanym okresie. Wszystko po to, by uniknąć jednoznacznych wyników badań faworyzujących dany model. Warto tutaj nadmienić, iż dobór przedsiębiorstw był w dużej mierze uwarunkowany dostępnością danych. Ze względu na ograniczone możliwości uzyskania danych finansowych przedsiębiorstw kwalifikujących się do próby badawczej uzyskano dane podmiotów z 12 województw. Natomiast liczba 50 przedsiębiorstw pozwala na uznanie badania za wiarygodne - mniejsza liczba badanych firm mogłaby nie w pełni oddać siłę prognostyczną poszczególnych modeli.

Do próby zaczerpnięto dane podmiotów z 12 województw. Szczegółową liczbę przedsiębiorstw pochodzącą z poszczególnych województw przedstawia tab. 1.

Tab. 1. Liczba przedsiębiorstw wchodzących w skład próby badawczej z poszczególnych województw

\begin{tabular}{|l|c|}
\hline \multicolumn{1}{|c|}{ Województwo } & Liczba przedsiębiorstw \\
\hline mazowieckie & 15 \\
\hline pomorskie & 6 \\
\hline śląskie & 6 \\
\hline wielkopolskie & 5 \\
\hline dolnośląskie & 4 \\
\hline kujawsko-pomorskie & 2 \\
\hline lubelskie & 2 \\
\hline lubuskie & 2 \\
\hline łódzkie & 2 \\
\hline małopolskie & 2 \\
\hline podkarpackie & 2 \\
\hline podlaskie & 2 \\
\hline razem & 50 \\
\hline
\end{tabular}

Źródło: opracowanie własne na podstawie zebranych danych

Co warte odnotowania, miejsce siedziby badanego przedsiębiorstwa nie wpływało na wyniki badań, zaś zróżnicowana liczba przedsiębiorstw z poszczególnych województw uwarunkowana była głównie dostępnością danych firm, które spełniały kryterium doboru próby badawczej.

Zabieg taki miał na celu zbadanie, czy modele stworzone przez ich twórców w różnym okresie badawczym oraz w oparciu bardzo często o różne próby (czy to pod względem wielkości przedsiębiorstw, czy też ich profilu działania) nadają się do wykorzystania przez analityków oraz audytorów do szerokiej puli przedsiębiorstw, tak jak zapewniają o tym autorzy poszczególnych modeli. Podjęto próbę odpowiedzi na jakże ważne pytanie: czy wprowadzenie kolejnego modelu wiąże się równocześnie ze wzrostem skuteczności prognostycznej takiego modelu w stosunku do swych poprzedników, na których w zdecydowanej większości opiera się jego konstrukcja.

Dodatkowo jako cel badawczy postawiono zadanie skonfrontowania ze sobą dwóch hipotez postawionych przez autorów metod, znawców problematyki finansowej i audytorskiej.

1. Pierwszą z hipotez poddanych weryfikacji było sprawdzenie trafności wypowiedzi A. Hołdy, który w swoim artykule napisał, iż metody nie mogą bazować na danych płynących 
z rachunku przepływów pieniężnych ze względu na wysoką dynamikę zmian (Hołda, 2001: 307-308).

2. Jako przeciwstawną wypowiedź przyjęto z kolei badania przeprowadzone przez T. Maślankę, który, konstruując metody, poddał weryfikacji wiarygodność płynącą ze wskaźników opartych na danych z rachunku przepływów pieniężnych (Maślanka, 2008).

Do tej pory w literaturze przedmiotu można spotkać więcej opinii oraz postaw przychylnych hipotezie pierwszej. Dobitnym tego przykładem jest liczba metod, które powstały, bazując tylko i wyłącznie na danych płynących z bilansu i rachunku wyników. Z kolei druga z postaw cieszy się mniejszą popularnością, a liczba metod dyskryminacyjnych, które korzystają z danych z cash flow, jakie można odnaleźć w literaturze przedmiotu, jest niewielka.

Zestawiając ze sobą te dwa poglądy, podjęto próbę odpowiedzi na pytanie, czy taka praktyka jest słuszna, czy może nie należałoby większej uwagi zwrócić również na dane, jakie można odnaleźć w rachunku z przepływów pieniężnych.

Spośród istniejących modeli dyskryminacyjnych przeanalizowano następujące ${ }^{1}$ :

- Elżbiety Mączyńskiej z 1994 roku,

- Jerzego Gajdki i Daniela Stosa z 1996 roku,

- Doroty Hadasik z 1998 roku,

- Doroty Appenzeller i Katarzyny Szarzec z 2004 roku,

- Elżbiety Mączyńskiej i Macieja Zawadzkiego z 1995 roku,

- Zmodyfikowany model Jerzego Gajdki i Daniela Stosa (zwany modelem II),

- Dariusza Wierzby z 2000 roku,

- Tomasza Maślanki z 2008 roku.

Wymienione powyżej modele zostały wybrane do badania ze względu na dużą popularność, jaką cieszą się w literaturze przedmiotu, głównie ze względu na wysoką skuteczność prognostyczną. Ponadto dobór metod do badania miał na celu skonfrontowanie ze sobą modeli powstałych po 2000 roku oraz tych, które stworzone zostały w latach 90 . XX wieku. Ponadto w badaniu zaprezentowano po dwa modele, które w późniejszych latach zostały zmodyfikowane przez samych twórców. Zabieg taki miał na celu ukazanie, czy metoda po korekcie rzeczywiście zwiększa swoją wiarygodność prognostyczną. Natomiast wybór konkretnej metody danego autora w przypadku, gdy stworzył on kilka modeli, był również podyktowany faktem wiarygodności - wybrano model, który miał najwyższą skuteczność według deklaracji samego autora.

Co ważne, by szerzej zgłębić poszczególne metody, warto sięgnąć do źródła publikacji danej metody - niestety bowiem w licznych opracowaniach można natrafić na różne jej interpretacje będące często wynikiem niedopatrzeń bądź błędów metodologicznych. Dodatkowo błędy te w wielu przypadkach są pogłębiane właśnie z tego powodu, iż autorzy publikacji sięgają nie do oryginalnych tekstów twórców metod, lecz innych publikacji, gdzie modele te zostały przedstawione niewłaściwie bądź w sposób niejasny, mało precyzyjny (Kitowski, 2011a).

W dalszej części pracy przedstawiono wyniki dla poszczególnych modeli, a następnie zaprezentowano zestawienie zbiorcze w ujęciu wiarygodności płynącej z otrzymanych wyników.

1 Więcej na temat powyższych modeli w: Mączyńska (1999), 42-45; Gajdka, Stos (1996), 57; Hadasik (1998), 166; Appenzeller, Szarzec (2004), 124-126; Maślanka (2008); Mączyńska, Zawadzki, Podruczna (1995), 71-76; Mączyńska (2004); Wierzba (2000), 79-104. 
PREZENTACJA I ANALIZA WYNIKÓW BADAŃ DLA POSZCZEGÓLNYCH MODELI

Tab. 2. Wyniki badań przeprowadzone w pierwszym analizowanym roku

\begin{tabular}{|c|c|c|c|c|c|c|c|c|}
\hline \multirow[b]{2}{*}{ 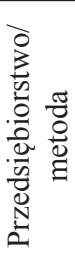 } & \multicolumn{8}{|c|}{ TWÓRCA MODELU DYSKRYMINACYJNEGO } \\
\hline & 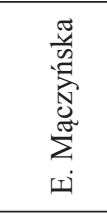 & 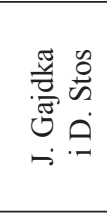 & $\begin{array}{l}\frac{y}{0} \\
\frac{\pi}{0} \\
\frac{\pi}{\pi} \\
\dot{0} \\
\dot{0}\end{array}$ & 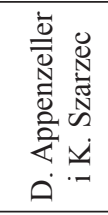 & 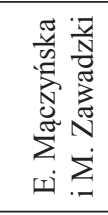 & 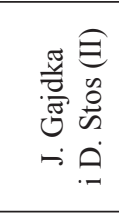 & $\begin{array}{l}\frac{\pi}{0} \\
\frac{0}{0} \\
\dot{0} \\
\dot{0}\end{array}$ & 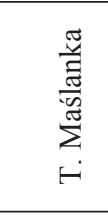 \\
\hline 1 & $-8,622$ & 17,869 & $-0,511$ & $-1,445$ & $-5,200$ & $-14,129$ & 0,043 & 0,414 \\
\hline 2 & 0,972 & 0,533 & 1,027 & 0,707 & 1,440 & $-0,073$ & 0,624 & 1,048 \\
\hline 3 & 1,359 & 0,627 & 0,140 & 0,345 & 2,151 & $-0,006$ & 0,690 & 0,637 \\
\hline 4 & 0,067 & 0,415 & 0,149 & $-0,102$ & 1,656 & $-0,295$ & 0,928 & 1,293 \\
\hline 5 & 2,852 & 0,886 & 1,500 & 1,275 & 4,248 & 0,495 & 1,115 & 2,746 \\
\hline 6 & 1,204 & 0,660 & 1,271 & 1,163 & 2,330 & 0,012 & 0,721 & 0,785 \\
\hline 7 & 3,427 & 0,901 & 0,966 & 1,158 & 3,794 & 0,509 & 1,196 & 1,961 \\
\hline 8 & $-0,808$ & 0,638 & 0,778 & 0,573 & 0,951 & $-0,449$ & 0,511 & 1,432 \\
\hline 9 & 1,019 & 0,543 & 1,454 & 1,339 & 2,857 & 0,114 & 0,817 & 0,884 \\
\hline 10 & 0,351 & 0,596 & $-0,103$ & 0,103 & 0,818 & $-0,357$ & 0,238 & 0,234 \\
\hline 11 & 1,841 & 0,769 & 1,155 & 3,141 & 4,592 & 0,641 & 2,222 & 0,858 \\
\hline 12 & $-0,669$ & 0,698 & 0,118 & 0,248 & 1,405 & $-0,476$ & 0,588 & 1,398 \\
\hline 13 & $-1,367$ & 10,118 & $-0,007$ & $-0,229$ & $-0,492$ & $-6,919$ & 0,371 & $-0,132$ \\
\hline 14 & 1,349 & 0,842 & 1,719 & 0,529 & 3,008 & 0,715 & 0,589 & 2,013 \\
\hline 15 & 0,787 & 0,727 & 0,1712 & 1,149 & 1,946 & $-0,125$ & 1,381 & 1,407 \\
\hline 16 & $-6,298$ & 0,023 & 1,600 & 0,211 & $-4,530$ & $-1,351$ & $-1,435$ & $-8,837$ \\
\hline 17 & $-0,942$ & 0,385 & 0,645 & 0,216 & 0,133 & $-0,492$ & 0,028 & 0,147 \\
\hline 18 & 1,392 & 0,579 & 0,243 & 0,074 & 1,606 & $-0,056$ & 0,356 & 0,175 \\
\hline 19 & $-1,219$ & 0,264 & 0,531 & 0,017 & $-0,944$ & $-0,644$ & $-0,041$ & $-0,137$ \\
\hline 20 & 5,190 & 0,789 & 1,504 & 2,135 & 7,494 & 0,749 & 1,224 & 3,866 \\
\hline 21 & 2,940 & 0,687 & 0,446 & 0,653 & 3,394 & 0,297 & 1,332 & 1,941 \\
\hline 22 & $-7,732$ & 0,145 & 0,307 & $-2,931$ & $-3,073$ & $-3,028$ & 0,077 & $-0,569$ \\
\hline 23 & 1,992 & 0,609 & 1,104 & 0,654 & 2,798 & 0,104 & $-0,167$ & $-0,531$ \\
\hline 24 & 1,915 & 0,605 & 1,176 & 0,295 & 2,938 & 0,157 & $-0,186$ & $-0,262$ \\
\hline 25 & 1,317 & 0,633 & 0,292 & 0,194 & 1,389 & 12,642 & 0,246 & 0,099 \\
\hline 26 & 1,497 & 0,639 & 1,428 & 1,504 & 3,558 & 0,146 & 1,122 & 1,941 \\
\hline 27 & 3,868 & 0,795 & 1,033 & 2,963 & 7,068 & 0,757 & 1,079 & 3,053 \\
\hline 28 & 2,701 & 0,367 & 0,132 & 0,429 & 2,450 & 0,204 & 0,801 & 3,170 \\
\hline 29 & $-3,167$ & 0,584 & 1,388 & 2,353 & $-0,120$ & $-0,576$ & 0,057 & $-3,919$ \\
\hline 30 & $-6,879$ & $-0,055$ & 0,635 & $-1,539$ & $-3,785$ & $-1,726$ & $-7,636$ & $-17,613$ \\
\hline 31 & $-1,961$ & 0,434 & 1,325 & 1,236 & 0,475 & $-0,331$ & $-0,045$ & $-3,261$ \\
\hline 32 & 0,621 & 0,565 & 1,449 & 1,236 & 2,846 & 0,097 & 0,359 & 0,840 \\
\hline 33 & $-0,380$ & 0,342 & 0,530 & 0,264 & 0,417 & $-0,390$ & $-0,157$ & 0,193 \\
\hline
\end{tabular}




\begin{tabular}{|l|c|c|c|c|c|c|c|c|}
\hline 34 & 1,115 & 0,493 & 1,227 & 0,931 & 2,098 & $-0,222$ & 0,651 & 2,196 \\
\hline 35 & 3,004 & 0,833 & 0,996 & 0,727 & 3,985 & 0,271 & 0,511 & 2,035 \\
\hline 36 & 3,084 & 0,845 & 1,068 & 0,407 & 4,056 & 0,222 & $-2,013$ & 0,549 \\
\hline 37 & 0,889 & 0,462 & 1,247 & 0,749 & 1,664 & $-0,135$ & 0,885 & 0,663 \\
\hline 38 & 1,571 & 0,574 & 0,879 & 4,589 & 5,319 & 0,503 & 2,256 & 1,204 \\
\hline 39 & 0,531 & 0,589 & 1,002 & 0,570 & 1,346 & $-0,255$ & 0,300 & 0,979 \\
\hline 40 & 0,978 & 0,624 & 0,922 & 0,262 & 2,029 & $-0,178$ & $-0,064$ & 2,195 \\
\hline 41 & $-1,236$ & 0,337 & 0,476 & $-0,025$ & $-0,942$ & $-0,633$ & $-0,972$ & $-0,191$ \\
\hline 42 & 1,462 & 1,317 & 1,057 & 0,633 & 1,839 & $-0,439$ & 0,744 & 1,210 \\
\hline 43 & $-30,849$ & $-3,099$ & 1,151 & $-1,269$ & $-2,043$ & $-8,229$ & $-1,672$ & $-0,140$ \\
\hline 44 & 1,43 & 0,66 & 1,31 & 0,79 & 3,214 & 0,179 & 0,391 & 2,083 \\
\hline 45 & 0,622 & 0,814 & 1,467 & 1,321 & 2,562 & 0,102 & 0,764 & 1,560 \\
\hline 46 & 2,085 & 0,215 & 0,817 & 0,576 & 1,598 & $-0,165$ & $-1,355$ & $-2,580$ \\
\hline 47 & 3,281 & 0,848 & 1,501 & 1,839 & 5,666 & 0,386 & 0,254 & 2,807 \\
\hline 48 & 0,415 & 0,712 & 1,451 & 0,089 & 1,122 & $-0,047$ & $-0,005$ & $-0,732$ \\
\hline 49 & $-0,650$ & 0,724 & 1,293 & 2,668 & 1,950 & $-18,931$ & 1,221 & $-1,449$ \\
\hline 50 & 2,504 & 0,838 & 1,337 & 1,678 & 4,334 & 0,836 & 0,477 & 0,637 \\
\hline
\end{tabular}

Źródło: opracowanie własne

Tab. 3. Wyniki badań przeprowadzone w drugim analizowanym roku

\begin{tabular}{|c|c|c|c|c|c|c|c|c|}
\hline \multirow[b]{2}{*}{ 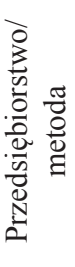 } & \multicolumn{8}{|c|}{ TWÓRCA MODELU DYSKRYMINACYJNEGO } \\
\hline & 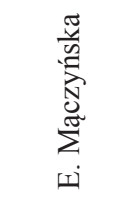 & 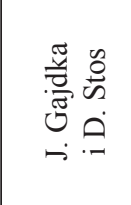 & 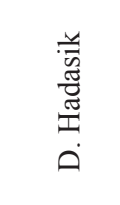 & 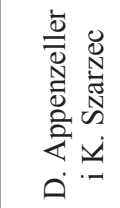 & 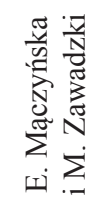 & 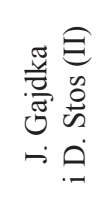 & 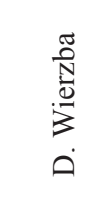 & 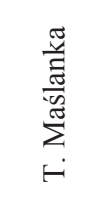 \\
\hline 1 & $-13,473$ & $-14,085$ & $-78,899$ & $-32,841$ & $-1,020$ & 0,963 & $-7,277$ & 0,367 \\
\hline 2 & $-0,976$ & 0,387 & 0,980 & 0,335 & $-0,198$ & $-0,420$ & $-0,087$ & $-0,165$ \\
\hline 3 & $-0,317$ & 0,487 & $-0,382$ & $-0,293$ & 0,329 & $-0,423$ & 0,080 & 0,065 \\
\hline 4 & $-0,393$ & 0,459 & $-0,389$ & $-0,464$ & 0,470 & $-0,507$ & 0,049 & $-0,348$ \\
\hline 5 & 0,863 & 0,962 & 0,045 & 0,674 & 2,636 & 0,012 & 0,612 & 0,795 \\
\hline 6 & 1,118 & 0,625 & 1,316 & 1,301 & 2,875 & 0,057 & 0,879 & 2,299 \\
\hline 7 & 0,141 & 4,487 & 0,961 & 0,541 & 1,364 & $-2,692$ & 0,401 & 0,694 \\
\hline 8 & $-1,420$ & 4,132 & 0,640 & 0,185 & 0,304 & $-2,836$ & 0,130 & 0,430 \\
\hline 9 & $-1,796$ & 0,009 & 0,426 & 0,022 & $-1,493$ & $-0,755$ & 0,635 & 0,809 \\
\hline 10 & $-3,833$ & 0,181 & $-0,806$ & $-0,952$ & $-3,121$ & $-1,944$ & $-0,571$ & $-0,218$ \\
\hline 11 & 2,059 & 0,766 & 0,756 & 3,162 & 4,666 & 0,882 & 1,763 & 0,697 \\
\hline 12 & 0,556 & 0,872 & $-0,223$ & 0,451 & 2,419 & $-0,190$ & 0,418 & 1,156 \\
\hline 13 & $-0,407$ & 12,378 & 0,331 & $-0,024$ & 0,406 & $-8,061$ & 0,135 & $-0,048$ \\
\hline 14 & $-7,544$ & $-0,464$ & $-0,631$ & $-1,795$ & $-5,423$ & $-2,337$ & $-1,820$ & $-2,339$ \\
\hline
\end{tabular}




\begin{tabular}{|c|c|c|c|c|c|c|c|c|}
\hline 15 & 0,166 & 0,533 & 0,6531 & 0,982 & 1,485 & $-0,256$ & 0,633 & 0,995 \\
\hline 16 & $-5,235$ & 10,755 & 1,497 & 0,572 & $-3,157$ & $-8,359$ & $-0,437$ & $-4,760$ \\
\hline 17 & $-1,292$ & 0,632 & 0,131 & $-0,319$ & $-0,956$ & $-1,027$ & $-0,171$ & $-0,081$ \\
\hline 18 & 1,089 & 0,616 & 0,700 & 0,435 & 1,996 & $-0,058$ & 0,553 & 0,842 \\
\hline 19 & 0,955 & 0,510 & 0,582 & 0,319 & 1,297 & $-0,167$ & 0,362 & 0,790 \\
\hline 20 & $-0,133$ & 0,494 & 0,616 & 0,350 & 1,103 & $-0,247$ & 0,351 & 0,145 \\
\hline 21 & $-0,337$ & 0,597 & $-0,369$ & $-0,160$ & 0,839 & $-0,406$ & 0,136 & $-0,150$ \\
\hline 22 & $-29,984$ & $-2,728$ & 0,101 & $-12,561$ & $-6,333$ & $-9,828$ & $-6,797$ & $-2,629$ \\
\hline 23 & 3,100 & 0,821 & 0,591 & 0,389 & 3,140 & 0,396 & 0,546 & 1,312 \\
\hline 24 & 1,017 & 0,593 & 1,103 & 0,342 & 2,047 & 0,061 & 0,421 & 0,527 \\
\hline 25 & 0,257 & 0,619 & 0,114 & $-0,052$ & 0,493 & $-1,585$ & 0,077 & $-0,025$ \\
\hline 26 & 0,867 & 0,556 & 1,354 & 0,975 & 2,564 & 0,009 & 0,907 & 0,998 \\
\hline 27 & 0,585 & 0,605 & 1,378 & 0,681 & 2,442 & 0,027 & $-0,143$ & 1,180 \\
\hline 28 & $-0,400$ & 0,192 & 0,249 & 0,132 & $-0,082$ & $-0,390$ & $-0,210$ & $-0,263$ \\
\hline 29 & 1,465 & 0,628 & 1,759 & 1,584 & 3,095 & 0,162 & 1,145 & 0,216 \\
\hline 30 & $-3,072$ & 0,440 & 1,567 & $-0,192$ & $-1,135$ & $-0,601$ & $-1,231$ & $-6,415$ \\
\hline 31 & $-4,494$ & 0,234 & 1,159 & 2,030 & $-2,777$ & $-0,630$ & $-0,182$ & $-8,754$ \\
\hline 32 & 0,875 & 0,599 & 1,454 & 1,159 & 2,911 & 0,157 & 0,542 & 1,369 \\
\hline 33 & 0,102 & 0,398 & 0,610 & 0,705 & 1,173 & $-0,238$ & 0,168 & 0,562 \\
\hline 34 & $-0,861$ & 0,446 & 1,146 & 0,668 & 0,293 & $-0,437$ & 0,017 & 0,515 \\
\hline 35 & 3,598 & 0,857 & 1,185 & 1,334 & 5,013 & 0,404 & 1,107 & 3,498 \\
\hline 36 & 1,634 & 0,958 & 0,768 & 1,204 & 2,666 & 0,016 & 0,504 & 1,653 \\
\hline 37 & 0,180 & 0,385 & 1,414 & 0,828 & 1,297 & $-0,121$ & 0,718 & 0,147 \\
\hline 38 & $-8,420$ & 0,079 & 1,382 & 1,827 & $-7,021$ & $-1,104$ & $-1,002$ & $-12,316$ \\
\hline 39 & $-3,241$ & 0,331 & 1,006 & $-0,040$ & $-1,777$ & $-0,878$ & $-0,994$ & $-1,874$ \\
\hline 40 & 1,266 & 1,811 & 1,155 & 0,304 & 2,909 & $-0,825$ & $-0,120$ & 3,879 \\
\hline 41 & $-0,488$ & 0,325 & 0,441 & 0,153 & $-0,148$ & $-0,482$ & $-0,743$ & 0,487 \\
\hline 42 & 1,919 & 0,921 & 1,057 & 0,745 & 2,461 & $-0,178$ & 0,839 & 1,181 \\
\hline 43 & $-119,676$ & $-14,817$ & $-14,544$ & $-58,216$ & $-2,147$ & $-40,273$ & $-1952,881$ & 2,260 \\
\hline 44 & 2,7 & 0,83 & 0,92 & 0,49 & 3,685 & 0,436 & 0,799 & 2,448 \\
\hline 45 & 0,112 & 0,559 & 1,099 & $-0,305$ & 1,114 & $-0,240$ & $-0,619$ & 0,439 \\
\hline 46 & 1,440 & 0,455 & 1,012 & 0,547 & 2,244 & $-0,002$ & 0,502 & 1,974 \\
\hline 47 & $-7,557$ & $-0,089$ & 0,433 & $-1,127$ & $-4,070$ & $-1,872$ & $-1,342$ & 6,454 \\
\hline 48 & 0,279 & 0,183 & 0,673 & 0,263 & $-0,832$ & $-0,629$ & 0,165 & $-0,230$ \\
\hline 49 & $-4,548$ & 0,417 & 0,736 & 4,436 & $-1,800$ & $-31,212$ & 1,963 & $-0,997$ \\
\hline 50 & $-0,020$ & 0,659 & 1,285 & 0,799 & 2,288 & 0,103 & 0,325 & 0,260 \\
\hline
\end{tabular}

Źródło: opracowanie własne 
Tab. 4. Wyniki badań przeprowadzone w trzecim analizowanym roku

\begin{tabular}{|c|c|c|c|c|c|c|c|c|}
\hline \multirow[b]{2}{*}{ 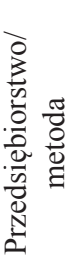 } & \multicolumn{8}{|c|}{ TWÓRCA MODELU DYSKRYMINACYJNEGO } \\
\hline & 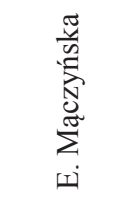 & 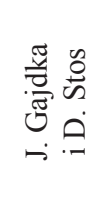 & $\begin{array}{l}\frac{1}{0} \\
\frac{\pi}{0} \\
\frac{\pi}{1} \\
\dot{0}\end{array}$ & 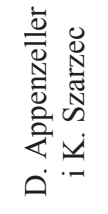 & 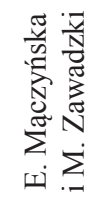 & 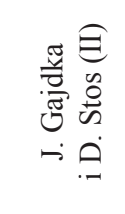 & $\begin{array}{l}\stackrel{0}{0} \\
\stackrel{0}{N} \\
\stackrel{0}{7} \\
0\end{array}$ & 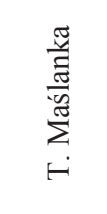 \\
\hline 1 & $-0,637$ & 1,535 & 1,241 & 1,145 & 0,496 & $-1,907$ & 0,270 & 6,823 \\
\hline 2 & $-5,025$ & $-0,005$ & 0,371 & $-0,307$ & $-4,627$ & $-1,054$ & $-1,502$ & $-3,048$ \\
\hline 3 & $-2,673$ & 0,355 & $-0,714$ & $-0,835$ & $-1,914$ & $-0,989$ & $-0,853$ & $-1,131$ \\
\hline 4 & $-0,016$ & 0,428 & 0,111 & 0,287 & 2,444 & $-0,373$ & 1,554 & 0,537 \\
\hline 5 & $-0,413$ & 0,841 & 0,679 & $-1,286$ & 0,934 & $-0,362$ & $-0,486$ & $-0,814$ \\
\hline 6 & $-0,438$ & 0,457 & 1,235 & 0,626 & 0,760 & $-0,313$ & 0,100 & $-0,102$ \\
\hline 7 & $-3,842$ & 4,849 & 1,021 & $-0,508$ & $-1,544$ & $-4,078$ & $-1,652$ & $-2,652$ \\
\hline 8 & $-0,854$ & 6,227 & 1,210 & 0,535 & 0,740 & $-4,005$ & $-0,018$ & $-0,590$ \\
\hline 9 & 3,329 & 0,976 & 0,937 & 0,955 & 3,554 & 0,216 & $-0,749$ & $-2,231$ \\
\hline 10 & $-9,853$ & $-0,139$ & $-1,328$ & $-1,600$ & $-9,174$ & $-4,255$ & $-2,251$ & $-0,522$ \\
\hline 11 & $-1,467$ & 0,515 & 0,958 & 0,606 & 0,710 & $-0,250$ & 0,399 & 0,611 \\
\hline 12 & $-1,428$ & 0,700 & $-0,277$ & $-0,504$ & 0,940 & $-0,684$ & $-0,510$ & $-0,143$ \\
\hline 13 & 0,030 & 11,248 & 0,327 & 0,061 & 0,754 & $-7,233$ & 0,089 & $-0,108$ \\
\hline 14 & $-6,213$ & $-0,035$ & $-0,436$ & $-2,309$ & $-3,835$ & $-2,202$ & $-1,875$ & $-2,202$ \\
\hline 15 & $-0,030$ & 0,462 & 0,5934 & 0,297 & 0,765 & $-0,289$ & 0,070 & 0,188 \\
\hline 16 & 0,105 & 47,205 & 1,151 & 0,794 & 0,739 & $-30,505$ & $-0,008$ & $-1,097$ \\
\hline 17 & 0,332 & 0,820 & 0,787 & 0,047 & 1,168 & $-0,255$ & 0,171 & 0,229 \\
\hline 18 & $-0,463$ & 0,452 & $-0,173$ & $-0,243$ & 0,389 & $-0,363$ & $-0,079$ & $-0,685$ \\
\hline 19 & $-0,011$ & 0,345 & 0,422 & 0,151 & 0,334 & $-0,298$ & 0,192 & $-0,037$ \\
\hline 20 & $-0,309$ & 0,790 & $-1,663$ & 13,120 & 8,893 & 1,232 & 5,466 & 9,885 \\
\hline 21 & 0,111 & 0,471 & $-0,383$ & $-0,059$ & 0,664 & $-0,316$ & 0,147 & 0,237 \\
\hline 22 & $-6,725$ & 0,972 & 0,612 & $-2,686$ & $-1,554$ & $-3,067$ & $-1,669$ & $-1,755$ \\
\hline 23 & $-0,523$ & 0,665 & 1,092 & 0,005 & 0,751 & $-0,406$ & 0,349 & 1,002 \\
\hline 24 & $-0,077$ & 0,519 & 0,578 & $-0,199$ & 0,592 & $-0,299$ & 0,054 & 0,529 \\
\hline 25 & 0,126 & 0,514 & 0,529 & 0,201 & 0,652 & $-4,299$ & 0,344 & 0,649 \\
\hline 26 & $-0,592$ & 0,372 & 0,722 & 0,089 & 0,225 & $-0,411$ & 0,047 & $-0,232$ \\
\hline 27 & $-0,263$ & 0,614 & 0,752 & 2,610 & 3,152 & 0,001 & 1,192 & 1,430 \\
\hline 28 & $-2,975$ & $-0,269$ & $-0,535$ & $-0,264$ & $-3,780$ & $-0,989$ & $-1,354$ & $-1,306$ \\
\hline 29 & $-1,766$ & 0,512 & 1,500 & 1,637 & 0,455 & $-0,317$ & 0,456 & 0,499 \\
\hline 30 & $-11,637$ & 0,916 & 1,654 & $-3,844$ & $-4,458$ & $-3,887$ & $-3,647$ & $-4,431$ \\
\hline 31 & $-1,976$ & 0,252 & 1,041 & 0,187 & $-0,806$ & $-0,469$ & $-0,391$ & $-2,067$ \\
\hline
\end{tabular}




\begin{tabular}{|r|r|r|r|r|r|r|r|r|}
\hline 32 & 0,638 & 0,545 & 1,421 & 1,105 & 2,364 & 0,064 & 0,629 & 0,557 \\
\hline 33 & $-0,146$ & 0,476 & 0,954 & 0,315 & 1,183 & $-0,204$ & $-0,050$ & 0,042 \\
\hline 34 & $-0,747$ & 0,264 & 0,845 & 0,406 & $-0,119$ & $-0,423$ & $-0,178$ & $-0,333$ \\
\hline 35 & 1,194 & 0,617 & 1,241 & 1,363 & 2,825 & $-0,033$ & 0,988 & 2,583 \\
\hline 36 & $-2,464$ & 0,453 & 1,064 & $-0,563$ & $-0,286$ & $-0,841$ & 0,115 & 2,856 \\
\hline 37 & $-0,060$ & 0,279 & 1,038 & 0,548 & 0,646 & $-0,220$ & 0,499 & $-0,156$ \\
\hline 38 & $-0,486$ & 0,480 & 1,346 & 2,625 & 2,089 & $-0,037$ & 1,059 & $-1,041$ \\
\hline 39 & $-1,134$ & 0,418 & 0,839 & 0,216 & $-0,153$ & $-0,552$ & $-0,286$ & $-0,447$ \\
\hline 40 & 0,073 & 6,549 & 0,894 & 1,577 & 2,431 & $-4,185$ & 1,500 & 6,040 \\
\hline 41 & $-4,390$ & 0,031 & 0,680 & $-0,184$ & $-3,175$ & $-1,156$ & $-1,968$ & $-2,310$ \\
\hline 42 & 0,213 & 0,680 & 0,986 & 0,513 & 0,664 & $-0,443$ & 0,286 & $-0,276$ \\
\hline 43 & $-18,171$ & $-1,291$ & $-0,480$ & $-5,667$ & 0,305 & $-5,886$ & $-8,376$ & 0,228 \\
\hline 44 & $-4,97$ & 0,22 & 0,5 & $-0,59$ & 2,205 & $-1,408$ & $-0,399$ & $-1,462$ \\
\hline 45 & $-0,320$ & 0,700 & 0,576 & $-0,338$ & $-0,126$ & $-0,569$ & $-0,140$ & 0,470 \\
\hline 46 & $-12,109$ & $-0,549$ & $-0,301$ & $-0,948$ & $-11,790$ & $-2,129$ & 0,321 & 1,593 \\
\hline 47 & 11,188 & 1,341 & 1,486 & 2,465 & 13,281 & 1,772 & 0,616 & 4,536 \\
\hline 48 & $-1,413$ & 0,363 & 0,618 & $-0,067$ & $-1,552$ & $-0,513$ & $-0,501$ & $-1,387$ \\
\hline 49 & 0,211 & 0,646 & 0,586 & 5,043 & 4,058 & $-6,553$ & 2,745 & 7,422 \\
\hline 50 & $-0,202$ & 0,632 & 1,438 & 0,416 & 2,041 & 0,087 & 0,167 & 0,359 \\
\hline
\end{tabular}

Źródło: opracowanie własne

Podsumowaniem przeprowadzonych badań jest zestawienie znajdujące się w tab. 5, która prezentuje klasyfikację modeli dyskryminacyjnych wg trafności otrzymanych wyników. Jako pozytywną diagnozę przyjęto wynik sugerujący złą kondycję finansową badanego przedsiębiorstwa. Zatem jeśli otrzymany wynik funkcji dyskryminacyjnej wskazywał na dobrą kondycję finansową, został klasyfikowany jako błędny.

Tab. 5. Trafność prognoz wg poszczególnych modeli na podstawie przeprowadzonych badań w analizowanych okresach

\begin{tabular}{|c|c|c|c|c|c|c|c|c|}
\hline \multirow[b]{2}{*}{$\begin{array}{c}\text { Rok } \\
\text { badania }\end{array}$} & \multicolumn{8}{|c|}{ Trafność prognoz wg poszczególnych modeli (w \%) } \\
\hline & 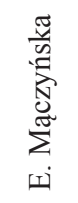 & 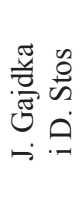 & $\begin{array}{l}\frac{y}{\vec{a}} \\
\frac{\pi}{0} \\
\frac{\pi}{\pi} \\
\dot{0}\end{array}$ & 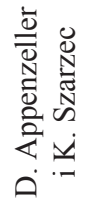 & 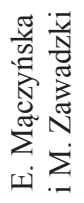 & 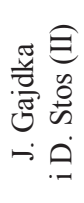 & $\begin{array}{l}\frac{\pi}{N} \\
\stackrel{0}{0} \\
\stackrel{0}{3} \\
\dot{0}\end{array}$ & 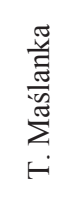 \\
\hline 1 & $30 \%$ & $84 \%$ & $22 \%$ & $14 \%$ & $18 \%$ & $56 \%$ & $26 \%$ & $28 \%$ \\
\hline 2 & $50 \%$ & $82 \%$ & $28 \%$ & $30 \%$ & $36 \%$ & $72 \%$ & $36 \%$ & $34 \%$ \\
\hline 3 & $76 \%$ & $80 \%$ & $26 \%$ & $40 \%$ & $32 \%$ & $88 \%$ & $46 \%$ & $52 \%$ \\
\hline
\end{tabular}

Źródło: opracowanie własne 
Na plan pierwszy trzeba w tym miejscu wysunąć model stworzony przez J. Gajdkę i D. Stosa. W tym miejscu należy zwrócić uwagę, iż właśnie te dwa modele - czyli model pierwotny oraz jego modyfikacja - wykazywały wysoką trafność prognostyczną. W ostatnim okresie badawczym wyższą wiarygodnością charakteryzował się model drugi, jednak biorąc pod uwagę cały okres badawczy, bardziej wiarygodne wyniki przedstawiał model pierwszy.

Analizując metody, które doczekały się swoich modyfikacji, warto także zwrócić uwagę na bardzo ciekawy przypadek - mianowicie modele, które są modyfikacją pierwotnych metod, nie zawsze są propozycją ciekawszą. Potwierdzeniem powyższego mogą być wyniki otrzymane na podstawie badań dla modelu E. Mączyńskiej oraz jej późniejszej modyfikacji przez Mączyńską razem z M. Zawadzkim. Drugi (późniejszy model), który miał być udoskonaleniem pierwotnej metody, okazał się mniej skutecznym prognostykiem, dającym słabe wyniki odnośnie do oceny poziomu kondycji finansowej w badanej próbie.

Poniżej 50\% skuteczności wykazały cztery modele, z czego na uwagę zasługuje m.in.model stworzony przez D. Wierzbę, który adaptował do polskich warunków model E. Altmana. Jednak, co godne podkreślenia, w swym modelu autor niefortunnie dwukrotnie stosuje wskaźnik o błędnym założeniu konstrukcyjnym (odejmowanie amortyzacji od wyniku z działalności operacyjnej, gdzie ta wartość jest już odejmowana). Jak się jednak okazało, cały zabieg nie miał w przypadku tej próby dużego znaczenia i nie wpłynął w sposób istotny na wyniki badania za pomocą modelu.

$\mathrm{Na}$ zakończenie, rozpatrując otrzymane wyniki, należy jeszcze podjąć dwie kwestie. Pierwsza: modele nowsze nie są wcale lepszym narzędziem badawczym niż metody powstałe wcześniej, będące często ich pierwowzorem.

Kolejny wniosek wart zauważenia wypływa z analizy wyników badania modelu, który w swej konstrukcji wykorzystywał dane płynące ze sprawozdania z rachunku przepływów pieniężnych. Otóż wprowadzenie do modelu danych zawartych w cash flow nie podnosi W sposób znaczący wartości prognostycznej modelu.

Poniżej zaprezentowano hierarchię metod dyskryminacyjnych wg trafności prognozy za ostatni rok badawczy - tab. 6 .

Natomiast w tab. 7 przedstawiono wiarygodność prognostyczną niektórych omawianych modeli, jaką wykazywały one w momencie ich konstrukcji - wiarygodność wg poszczególnych autorów oraz podobne tego typu badania, na jakie można napotkać, studiując literaturę przedmiotu. 
Tab. 6. Hierarchia modeli dyskryminacyjnych na podstawie przeprowadzonych badań w ostatnim analizowanym roku

\begin{tabular}{|c|l|c|}
\hline $\begin{array}{c}\text { Miejsce modelu na podstawie } \\
\text { otrzymanych wyników }\end{array}$ & \multicolumn{1}{|c|}{ Autor modelu } & $\begin{array}{c}\text { Trafność } \\
\text { prognozy modelu }\end{array}$ \\
\hline 1. & J. Gajdka i D. Stos „Model II” & $88 \%$ \\
\hline 2. & J. Gajdka i D. Stos & $80 \%$ \\
\hline 3. & E. Mączyńska & $76 \%$ \\
\hline 4. & T. Maślanka & $52 \%$ \\
\hline 5. & D. Wierzba & $46 \%$ \\
\hline 6. & D. Appenzeller i K. Szarzec & $40 \%$ \\
\hline 7. & E. Mączyńska i M. Zawadzki & $32 \%$ \\
\hline 8. & D. Hadasik & $26 \%$ \\
\hline
\end{tabular}

Źródło: opracowanie własne

Tab. 7. Porównanie wyników różnych badań oraz deklarowanej wartości prognostycznej autorów metod dyskryminacyjnych

\begin{tabular}{|c|c|c|c|c|c|c|}
\hline \multirow[b]{2}{*}{$\begin{array}{c}\text { System } \\
\text { wczesnego } \\
\text { ostrzegania } \\
\text { autorstwa }\end{array}$} & \multirow[b]{2}{*}{$\begin{array}{c}\text { Deklarowana } \\
\text { wartość wg } \\
\text { autorów metod }\end{array}$} & \multirow[b]{2}{*}{$\begin{array}{l}\text { Wyniki prze- } \\
\text { prowadzonej } \\
\text { analizy za ostatni } \\
\text { okres badania } \\
\text { autora }\end{array}$} & \multicolumn{4}{|c|}{ Skuteczność metod wg: } \\
\hline & & & 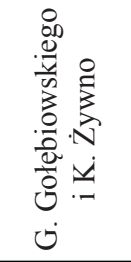 & 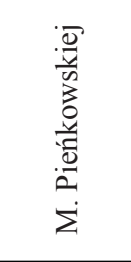 & 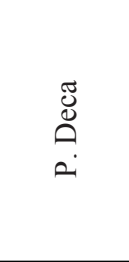 & 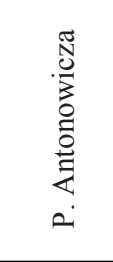 \\
\hline E. Mączyńskiej & b. d. & $76 \%$ & - & - & - & - \\
\hline $\begin{array}{l}\text { J. Gajdki } \\
\text { i D. Stosa }\end{array}$ & $93,00 \%$ & $80 \%$ & $66,67 \%$ & $38,80 \%$ & $47,50 \%$ & $78,24 \%$ \\
\hline $\begin{array}{l}\text { E. Mączyńskiej } \\
\text { i M. Zawadzkiego }\end{array}$ & b. d. & $32 \%$ & $100,00 \%$ & $100,00 \%$ & $80,00 \%$ & $85,66 \%$ \\
\hline D. Hadasik & $95,74 \%$ & $26 \%$ & $60,00 \%$ & - & $76,92 \%$ & - \\
\hline $\begin{array}{l}\text { D. Appenzeller } \\
\text { i K. Szarzec }\end{array}$ & $85,00 \%$ & $40 \%$ & $100,00 \%$ & $79,60 \%$ & $100,00 \%$ & $88,22 \%$ \\
\hline
\end{tabular}

Źródło: opracowanie własne na podstawie przeprowadzonych badań, danych źródłowych oraz Gołębiowski, Tłaczała (2009: 256) 


\title{
WYKORZYSTANIE PUNKTOWEJ METODY OCENY RYZYKA BANKOWEGO
}

\author{
WG WARIANTU A. HOŁDY
}

Należy w tym miejscu zaznaczyć, iż otrzymane wartości płynące z modeli dyskryminacyjnych są bardzo zróżnicowane. Dlatego, jako swego rodzaju weryfikator, poniżej zaprezentowano wyniki badań z ostatniego analizowanego okresu przy wykorzystaniu innego narzędzia, jakim jest modyfikacja punktowej metody oceny ryzyka bankowego zaproponowanej przez A. Hołdę ${ }^{2}$.

Wariant stworzonej przez Hołdę metody pozwala na określenie za pomocą wskaźników finansowych miejsca badanego przedsiębiorstwa w danej branży (Hołda, 2002).

Tab. 8. Wyniki badań przeprowadzonych w ostatnim analizowanym okresie przy wykorzystaniu punktowej metody oceny ryzyka bankowego wg wariantu Artura Hołdy

\begin{tabular}{|c|c|c|}
\hline Przedsiębiorstwo & $\begin{array}{c}\text { Liczba uzyskanych } \\
\text { punktów }\end{array}$ & $\begin{array}{l}\text { Miejsce przedsiębiorstwa } \\
\text { w branży }\end{array}$ \\
\hline 1 & 23 & dobre \\
\hline 2 & 16 & standardowe \\
\hline 3 & 16 & standardowe \\
\hline 4 & 14 & bardzo niskie \\
\hline 5 & 14 & bardzo niskie \\
\hline 6 & 19 & standardowe \\
\hline 7 & 17 & standardowe \\
\hline 8 & 20 & standardowe \\
\hline 9 & 18 & standardowe \\
\hline 10 & 13 & bardzo niskie \\
\hline 11 & 20 & dobre \\
\hline 12 & 16 & standardowe \\
\hline 13 & 17 & standardowe \\
\hline 14 & 13 & bardzo niskie \\
\hline 15 & 18 & standardowe \\
\hline 16 & 20 & standardowe \\
\hline 17 & 15 & bardzo niskie \\
\hline 18 & 16 & standardowe \\
\hline 19 & 20 & standardowe \\
\hline 20 & 25 & dobre \\
\hline 21 & 18 & standardowe \\
\hline
\end{tabular}

${ }^{2}$ Warto nadmienić, iż jest to tylko jeden z wariantów tzw. metod bankowych. Szerzej na temat opisu metod bankowych oraz możliwych podziałów w: J. Kitowski (2011b), Metodyczne aspekty kryteriów bankowej oceny kondycji finansowej przedsiębiorstwa. 


\begin{tabular}{|c|c|c|}
\hline 22 & 20 & standardowe \\
\hline 23 & 17 & standardowe \\
\hline 24 & 14 & bardzo niskie \\
\hline 25 & 17 & standardowe \\
\hline 26 & 17 & standardowe \\
\hline 27 & 26 & dobre \\
\hline 28 & 15 & bardzo niskie \\
\hline 29 & 20 & standardowe \\
\hline 30 & 14 & bardzo niskie \\
\hline 31 & 15 & bardzo niskie \\
\hline 32 & 19 & standardowe \\
\hline 33 & 16 & standardowe \\
\hline 34 & 17 & standardowe \\
\hline 35 & 18 & standardowe \\
\hline 36 & 15 & bardzo niskie \\
\hline 37 & 19 & standardowe \\
\hline 38 & 26 & dobre \\
\hline 39 & 17 & standardowe \\
\hline 40 & 20 & standardowe \\
\hline 41 & 16 & standardowe \\
\hline 42 & 17 & standardowe \\
\hline 43 & 23 & dobre \\
\hline 44 & 22 & standardowe \\
\hline 45 & 15 & bardzo niskie \\
\hline 46 & 14 & bardzo niskie \\
\hline 47 & 21 & standardowe \\
\hline 48 & 13 & bardzo niskie \\
\hline 49 & 22 & standardowe \\
\hline 50 & 20 & standardowe \\
\hline
\end{tabular}

Źródło: opracowanie własne

Na podstawie przeprowadzonych badań przy zastosowaniu metody oceniającej miejsce badanego przedsiębiorstwa na tle branży otrzymano następujące wyniki - ogółem:

- bardzo niskie - 13 przedsiębiorstw (26\%),

- standardowe - 31 przedsiębiorstw (62\%),

- dobre - 6 przedsiębiorstw (12\%),

- bardzo dobre - 0 przedsiębiorstw (0\%). 
Modyfikacja metody punktowej to swoisty weryfikator. W sposób odmienny pozwala na stwierdzenie pozycji przedsiębiorstwa na rynku. Zatem w sposób obiektywny otrzymane wyniki można zestawić z diagnozą metody punktowej, aby poszerzyć obraz porównawczy.

\section{AKTUALNOŚĆ I POWSZECHNOŚĆ METOD DYSKRYMINACYJNYCH}

Na zakończenie warto podkreślić najważniejszy wniosek, wypływający z rozważenia aktualności metod dyskryminacyjnych. Ich obecność w literaturze przedmiotu oraz praktyce badawczej w dalszym ciągu nie podlega dyskusji. Jest to nadal dominująca grupa metod wykorzystywana przez osoby z kręgu zarządzania finansami i analizy finansowej. Dobitnym tego przykładem są chociażby otrzymane wyniki, gdzie funkcje z lat 90 . nadal potrafią trafnie weryfikować kondycję badanej próby. Również potwierdzeniem powyższego jest fakt powstawania obecnie coraz to nowszych modeli wykorzystujących funkcję dyskryminacyjną oraz ich odmian i modyfikacji (Korol, 2010).

Dodatkowo, jak wynika z rozważań, modele dyskryminacyjne oprócz swej wiarygodności charakteryzują się prostotą w interpretacji swoich wyników. Sprawia to, że nawet osoba niemająca gruntownego wykształcenia z zakresu analizy finansowej nie powinna mieć problemów w interpretacji otrzymanych wyników. Czyni to również modele szybkim i sprawnym narzędziem diagnostycznym. Powyższe argumenty przemawiają za tym, że metody te są nadal bardzo popularne, stąd też w dalszym ciągu można zauważyć ich wykorzystywanie w tworzeniu coraz to nowych modeli ${ }^{3}$.

\section{Podsumowanie}

W tym miejscu należy jednak zaznaczyć, co dobitnie przedstawiają wyniki przeprowadzonych badań, że mimo popularności metod dyskryminacyjnych przy przeprowadzaniu badań należy bazować również na innych sposobach pozwalających na ocenę kondycji danego przedsiębiorstwa. Jest to podyktowane faktem, iż nie można ulegać fascynacji tylko i wyłącznie jednym sposobem weryfikacji i warto szerzej zgłębić przeprowadzaną analizę. Tego przykładem jest chociażby zastosowanie w powyższym artykule modelu bazującego na ocenie nie samej kondycji przedsiębiorstwa, ale ukazującego też jego pozycję na danym rynku. Jest to poszerzenie analizy, dzięki któremu można otrzymać dodatkowe informacje o wycenie przedsiębiorstwa, a także spectrum porównawcze będące bardziej wiarygodną oceną finansową badanego podmiotu. Takie podejście uczyni analizę bardziej szczegółową

3 Jako przykład można podać chociażby metodę stworzoną przez P. Ciesielskiego (patrz: Prognozowanie upadłości podmiotów gospodarczych w Polsce). 
i pozwoli na wyeliminowanie potencjalnych błędów. Umożliwi równocześnie szerszą i dokładniejszą ocenę analizowanego przedsiębiorstwa.

Warto także mieć na uwadze, iż choć przeprowadzone badanie jest w pełni wiarygodne, to jednak należy zachować pewien dystans do otrzymanych wyników. Po przeanalizowaniu wielu podobnych doświadczeń przeprowadzanych na przestrzeni lat przez badaczy przedmiotu okazuje się, że wykonywanie badań na innej próbie może wiązać się z mniej lub bardziej odmiennymi wynikami. Dzieje się tak choćby z powodu wielkości próby czy specyfiki branżowej przedsiębiorstw poddawanych analizie, o czym była mowa wcześniej. Dlatego mimo iż przeprowadzone badanie przedstawia wiarygodne wyniki, to warto prowadzić kolejne tego typu analizy w celu uchwycenia zmian, jakie mogą mieć miejsce. Warto także poszukiwać nowych narzędzi prognostycznych pozwalających w sposób relatywnie wysoki oceniać stan badanych przedsiębiorstw.

\section{Literatura}

\section{References}

Appenzeller, D., Szarzec, K. (2004). Prognozowanie zagrożenia upadłością polskich spółek publicznych. Rynek Terminowy, 1, 124-126.

Ciesielski, P. (2005). Prognozowanie upadłości podmiotów gospodarczych w Polsce. Rachunkowość, 8,15 .

Gajdka, J., Stos, D. (1996). Wykorzystanie analizy dyskryminacyjnej w ocenie kondycji finansowej przedsiębiorstwa. W: R. Borowiecki (red). Restrukturyzacja w procesie przekształceń i rozwoju przedsiębiorstw. Kraków: Wydawnictwo Akademii Ekonomicznej, 57.

Gołębiowski, G., Tłaczała A. (2009). Analiza finansowa w teorii $i$ w praktyce. Warszawa: 256.

Hadasik, D. (1998). Upadłość przedsiębiorstw w Polsce i metody jej prognozowania. Zeszyty Naukowe Seria II Prace habilitacyjne, 166.

Hołda, A. (2001). Prognozowanie bankructwa jednostki w warunkach gospodarki polskiej z wykorzystaniem funkcji dyskryminacyjnej ZH. Rachunkowość, 5, 307-308.

Hołda, A. (2002). Ustalanie sytuacji finansowej jednostki z wykorzystaniem mierników syntetycznych - koncepcja wartości średnich. Monitor Rachunkowości i Finansów,1, 42-46.

Kitowski, J. (1997). Rachunkowość i finanse. Przemyśl: Wydawnictwo Wyższej Szkoły Administracji i Zarządzania.

Kitowski, J. (2011a). Analiza finansowa - bariery dydaktyczne (w świetle krajowej literatury przedmiotu). W: A. Gospodarowicz (red.), Dydaktyka finansów na kierunku finanse i rachunkowość. Materiaty Konferencyjne Uniwersytetu Ekonomicznego we Wrocławiu. Wrocław: Wydawnictwo Uniwersytetu Ekonomicznego we Wrocławiu, 55-63.

Kitowski, J. (2011b). Metodyczne aspekty kryteriów bankowej oceny kondycji finansowej przedsiębiorstwa. W: B. Bernaś, A. Kopiński (red.). Zarzązanie finansami firm - teoria i praktyka. Wrocław: Wydawnictwo Uniwersytetu Ekonomicznego we Wrocławiu, 41-57.

Korol, T. (2010). Prognozowanie upadłości firm przy wykorzystaniu kursu dolara oraz logiki rozmytej. Przeglad Organizacji,1, 35-38.

Maślanka, T. (2008). Przepływy pieniężne w zarządzaniu finansami przedsiębiorstw. Warszawa: C.H. Beck.

Mączyńska, E. (1999). Ocena kondycji przedsiębiorstwa (Uproszczone metody). Życie Gospodarcze, $38,42-45$. 
Mączyńska, E. (2004). Globalizacja ryzyka a systemy wczesnego ostrzegania. W: D. Appenzeller, Upadtość przedsiębiorstw w Polsce w latach 1990-2003. Poznań: Wydawnictwo Akademii Ekonomicznej.

Mączyńska, E., Zawadzki, M., Podruczna, M. (1995). Agregatowe wskaźniki sytuacji ekonomicznej jako narzędzie kontroli przedsiębiorstw państwowych przez organy założycielskie. Prace Naukowe Akademii Ekonomicznej we Wroctawiu, 698, 71-76.

Wierzba, D. (2000). Wczesne wykrywanie przedsiębiorstw zagrożonych upadłością na podstawie analizy wskaźników finansowych - teoria i badania empiryczne. Zeszyty Naukowe Wyższej Szkoły Ekonomiczno-Informacyjnej w Warszawie, 9, 79-104.

Rafal Pitera, mgr ekonomii, absolwent Uniwersytetu Rzeszowskiego.

Absolwent Wydziału Ekonomii, od kilku lat związany z dziedziną bankowości. Główne obszary zainteresowań: sprawozdawczość i analiza finansowa, badanie i ocena kondycji finansowej przedsiębiorstw za pomocą modeli bankowych oraz metod dyskryminacyjnych, ocena zdolności kredytowej podmiotów ubiegających się o kredyt.

Rafal Pitera graduated from the Department of Economics and is currently an employee at PLUS BANK SA in Rzeszów. For several years now he is associated with the field of banking. The main areas of his interest include: reporting and financial analysis, examination and the evaluation of the financial position of corporation with banking models and methods of discrimination and the evaluation of the creditworthiness of applicants for credit.

\section{Adres/address:}

Kancelaria Usług Finansowo-Księgowych „Doradca”

ul. Trembeckiego 11, 35-234 Rzeszów, Polska

e-mail: rafalpitera@onet.eu 